\title{
The influence of lipoprotein lipase gene polymorphism in Czech East Friesian sheep on the fatty acid profile in milk and yoghurt drinks - a preliminary study
}

\author{
Z. Sztankoova ${ }^{1,3}$, M. Borková2, J. Rychtářová1, J. Smolová2, O. Elich², M. Švejcarová2 \\ and M. Brzáková ${ }^{1}$ \\ ${ }^{1}$ Institute of Animal Science, Přátelství 815, 10400 Prague Uhř́něves, Czech Republic \\ ${ }^{2}$ Dairy Research Institute, Ke Dvoru 12a, 16000 Prague, Czech Republic
}

KEY WORDS: fatty acids, genetic polymorphism, lipoprotein lipase, sheep milk, yoghurt drink

Received: 18 March 2020

Revised: 25 February 2021

Accepted: 1 March 2021

${ }^{3}$ Corresponding author:

e-mail: sztankoova@seznam.cz

\begin{abstract}
The aim of the study was to evaluate the influence of single nucleotide polymorphism (SNP) in lipoprotein lipase gene (LPL) on the basic sheep milk parameters and the fatty acid profile in milk and yoghurt drinks made from it. The Primer Extension Analysis was used for genotyping 3 SNPs at positions: $74(\mathrm{~T} / \mathrm{C}), 130(\mathrm{~T} / \mathrm{C})$ and $133(\mathrm{~T} / \mathrm{A})$ in the $3^{\prime} \mathrm{UTR}$ region of the ovine $L P L$ gene in 139 sheep of the East Friesian breed. According to the $L P L$ genetic marker (CCCCAA and CTCTAT) 40 sheep were selected and divided into groups. Pooled milk was collected from May to June and used to make yoghurt drinks with probiotics and prebiotics according to the genetic combination. In the pooled samples used for yoghurt production, the contents of fat, protein, lactose and total solids have been determined. The profile of fatty acids in fat from milk pooled samples as well as from yoghurt drinks has been analysed. Differences in the composition of milk and fatty acid profile were shown. The content of fat and total solids was significantly higher in the milk with the CTCTAT genotype combination in comparison to that with CCCCAA genotype. Moreover, these samples of milk and yoghurt products had a statistically lower content of palmitic acid and a significantly lower content of hypocholesterolemic acids. Targeted production of sheep milk from animals with different genotypes of the LPL may positively influence the fatty acid profile in milk and products made from it.
\end{abstract}

\section{Introduction}

Sheep milk and products made from it are a source of valuable nutritional substances for human nutrition. In comparison to cow milk, sheep milk contains a higher content of milk fat and it is composited of a higher proportion of polyunsaturated fatty acids (PUFA), especially essential $\alpha$-linolenic acid and conjugated linoleic acid (CLA). Also, a lower saturated fatty acid (SFA) content is present in sheep milk than in cow and goat milk (Moioli et al., 2012; Markiewicz-Kęszycka et al., 2013).
Modification of the fatty acid (FA) profile in milk fat with a possibility of increasing the content of nutritionally essential FAs, such as n-3 FA especially CLA, has been an object of many types of research (Reynolds et al., 2006; Sánchez et al., 2010; Moioli et al., 2012; Buccioni et al., 2015). Crucial factors influencing the FA profile in sheep milk are feed composition, lactation stage, breed, and last but not least, genetic factors. Fatty acids essential for milk fat triacylglycerols (TAG) synthesis in the mammary gland are obtained in two ways. The one is de novo synthesis in the secretory cells of the 
mammary gland. The other source is their uptake from the blood, from circulating plasma lipoproteins and non-esterified FAs produced during lipid absorption from the digestive tract and the reserve adipose tissue mobilization. It applies to all FAs having 18 carbons and more (Bauman and Griinari, 2003; Shingfield et al., 2013). The release of FAs in the mammary gland is a complex process influenced by many lipogenic enzymes like FA synthase (FASN), acetyl Co-A carboxylase (ACACA), stearoyl-CoA desaturase (SCD) and lipoprotein lipase (LPL) (Palmquist, 2006; Ogorevc et al., 2009; Crisà et al., 2010). These enzymes are encoded by their genes FASN, ACACA, SCD and $L P L$, respectively; however, genetic polymorphism may affect their expression. A study of the influence of polymorphism of selected candidate genes of lipogenic enzymes can provide new knowledge of their impact on the FA profile in milk and its products (Bouwman et al., 2011; Marchitelli et al., 2013).

The $L P L$ gene encodes a key enzyme lipoprotein lipase which plays an important role in milk and milk fat synthesis during lactation. Crisà et al. (2010) and Hidayati et al. (2015) reported LPL gene diversity in some sheep breeds and its association both with milk composition, including FA composition and CLA. The ovine $L P L$ gene is located on OAR chromosome 2 (www.animalgenome.org/cbi-bin/ QTLdb/OA). It consists of 10 exons and 9 introns, and its full-length is 3,529 bp with a 178-bp 5'UTR, followed by a 1,434-bp open reading frame and a 1,917-bp 3'UTR (Bonnet et al., 2000). This enzyme participates in the hydrolysis of TAGs, which are a part of chylomicrons and very-low-density lipoproteins (VLDL) (Barber et al., 1997), and is essential for FA import into the mammary gland cells (Crisà et al., 2010).

Based on the above data, it was hypothesised that the single nucleotide polymorphism (SNP) of $L P L$ might play an important role in milk and its fat composition. Therefore, the aim of the study was to evaluate the association between the genotype combination of the $L P L$ gene and the FA profile in sheep milk and yoghurt drinks in the herd of East Friesian sheep kept in the Czech Republic.

\section{Material and methods}

The experiment was carried out in accordance with Directive 2010/63/EU of the European Parliament and European Council of September 22,2010 , on the protection of animals used for scientific purposes.

\section{Animals, diets and sample collection}

The experiment was performed on a bio farm in spring from May to June 2017. From a herd of 139 animals, 40 East Frisian dairy sheep (between $4^{\text {th }}$ and $6^{\text {th }}$ lactation) were divided into two genetic groups according to the combination genotypes $(74 \mathrm{~T} / \mathrm{C}),(130 \mathrm{~T} / \mathrm{C})$ and $(133 \mathrm{~T} / \mathrm{A})$, respectively of $L P L$ locus. Genotype combination CCCCAA was present in a group A and CTCTAT in a group B (Table 1). Animals with genetic combination TTTTTT were not included in the study as it was a small number of such animals in the analyzed flock of the $L P L$ locus.

Table 1. Group of animals divided by genotype of lipoprotein lipase gene ( $L P L)$ locus, and genotype frequencies of $L P L$ locus in the observed East Friesian Sheep population

\begin{tabular}{llll}
\hline Group & $\begin{array}{l}\text { Group by single } \\
\text { nucleotide } \\
\text { polymorphism (SNPs) }\end{array}$ & $\begin{array}{l}\text { Genotype fre- } \\
\text { quency, \% }\end{array}$ & $\begin{array}{l}\text { Number of } \\
\text { animals }\end{array}$ \\
\hline A & CC/CC/AA & 33.8 & 47 \\
B & CT/CT/AT & 54.7 & 76 \\
$\mathrm{C}^{2}$ & TT/TT/TT & 11.5 & 16 \\
\hline
\end{tabular}

${ }^{1}$ SNPs $74 / 130 / 133 ;{ }^{2}$ not further analysed

Animals were housed indoors, and were fed hay ad libitum, haylage $(3.0 \mathrm{~kg} / \mathrm{animal} / \mathrm{day})$, and a grain mix of $50 \%$ maize, $25 \%$ barley and $25 \%$ oats (1.0 kg/animal/day). Sheep had ad libitum access to water and mineral licks.

Ewes were machine-milked twice a day. Milk samples were collected three times (May 15, June 6 and June 21, 2017) during lactation from the morning milking. For each collection, 2 pooled milk samples were made for each group. Each sample provided two different pooled samples for groups A and B, separately. Pooled samples were made concerning the lactation phases of the animals.

Genomic DNA was extracted from whole blood samples using a GeneAll ${ }^{\circledR}$ Exgene ${ }^{\mathrm{TM}}$ Blood SV mini kit (GeneAll Biotechnology Co., Ltd., Seoul, Korea) according to manufacturer's recommendactions.

\section{DNA amplification}

A 331-bp fragment of 3'UTR of the LPL locus was amplified in polymerase chain reaction (PCR) using a pair of primers: forward 5'-TgggCAAAgCTACggAAgAAA-3', reverse 5'-ggACAgAATgCA gTgCTTTTCA-3', designed based on the GenBank sheep sequence (No. GQ150554.1.) and Primer3Plus software (Untergasser et al., 2012).

The PCR was performed in a $15 \mu$ l reaction mixture consisting of $3 \mu \mathrm{l}$ genomic DNA (10-100 ng), 1× PPP Master Mix (Top Bio Ltd., Prague, 
Czech Republic) and $0.8 \mu \mathrm{M}$ of each primer (GENERI Biotech Ltd., Prague, Czech Republic). PCR reaction of 331-bp amplicon was conducted using a Touchdown (TD) PCR reaction (Korbie and Mattick, 2008). Thermal cycling conditions were optimized to our laboratory conditions and performed as follows: an initial denaturation step at $95{ }^{\circ} \mathrm{C}$ for $2 \mathrm{~min}$, followed by 15 cycles each of denaturation at $94{ }^{\circ} \mathrm{C}$ for $45 \mathrm{~s}$, annealing at variable temperatures for $35 \mathrm{~s}$, and extension at $72{ }^{\circ} \mathrm{C}$ for $2 \mathrm{~min}$. In the first cycle, the annealing temperature was set to $64{ }^{\circ} \mathrm{C}$, and for each of the 14 subsequent cycles, the annealing temperature was decreased by $0.5^{\circ} \mathrm{C}$ (i.e., it varied from $64{ }^{\circ} \mathrm{C}$ to $56.5^{\circ} \mathrm{C}$ at $0.5^{\circ} \mathrm{C}$ decrements along with the 15 cycles). This was followed by 20 cycles each at $95{ }^{\circ} \mathrm{C}$ for $30 \mathrm{~s}$, at $57^{\circ} \mathrm{C}$ for $35 \mathrm{~s}$ and $2 \mathrm{~min}$ at $72{ }^{\circ} \mathrm{C}$; with a final elongation step at $72{ }^{\circ} \mathrm{C}$ for $4 \mathrm{~min}$ (TGradient 96 Thermocycler; Biometra $\mathrm{GmbH}$, Göttingen, Germany). After the last PCR cycle, the samples were cooled at $4{ }^{\circ} \mathrm{C}$. The quality of the PCR product was verified by $3 \%$ agarose gel (gel electrophoresis using a $1 \times$ TBE) stained with ethidium bromide, and visualized under UV light and using Gene Ruler 50 bp Ladder (Top Bio Ltd., Prague, Czech Republic).

\section{Genotyping by SNaP shot}

The PCR products were purified by using the FastAP Thermosensitive Alkaline Phosphatase and Exonuclease I (Fermentas - Thermo Fisher Scientific, Waltham, MA, USA) to remove unincorporated ddNTPs, incubated at $37^{\circ} \mathrm{C}$ for $45 \mathrm{~min}$, followed by a denaturation step at $85^{\circ} \mathrm{C}$ for $15 \mathrm{~min}$ typed with the SnaPshot ddNTP Primer Extension Kit (Applied Biosystems, Foster City, CA, USA). The extension primer used in the typing procedure was SBE1: 5'-CCAgTgCTTTAgATggTg-3' (positions 75 to 82); SBE2 5'-TGAgTATTAACCCCAgCTCTAg-3', (positions 108 to 129); and SBE3 5'-ATTAgTTATTTTAAgATACAgTCTC-3' (positions 134 to 138) with regard to $L P L$ gene sequence no. GQ150554.1. For electrophoresis, $0.5 \mu 1$ of purified multiplex SBE reaction was mixed with $0.5 \mu 1$ of GeneScan-120 LIZ size standard (Applied Biosystems, Foster City, CA, USA) and $10 \mu 1$ of Hi-Di ${ }^{\mathrm{TM}}$ Formamide (Applied Biosystems, Foster City, CA, USA) and denatured at $95^{\circ} \mathrm{C}$ for $5 \mathrm{~min}$. The samples were subsequently electrophoresed on an ABI PRISM 3130-Avant Genetic Analyser (Applied Biosystems, Foster City, CA, USA), after which the data were analyzed and evaluated using GeneMapper ver. 3.5 software (Applied Biosystems, Foster City, CA, USA).

\section{Yoghurt drinks}

Cooled pooled milk samples were transported into the laboratory and used to produce 12 yoghurt drinks. The milk was analysed for fat, protein and total solids by a Dairy Spec FT IR milk analyser (Bentley Instruments, Inc., Chaska, MN, USA). To increase the nutritional impact of the product, yoghurt drinks were made with probiotic bacteria Bifidobacterium animalis subsp. lactis and Lactobacillus acidophilus and with the Orafti P95 prebiotic based on chicory inulin. Ten grams of chicory-based inulin prebiotics (Orafti P95, Beneo GmBH, Mannheim, Germany) were added into $190 \mathrm{~g}$ of sheep milk and pasteurized at $84{ }^{\circ} \mathrm{C}$ for $10 \mathrm{~min}$. After cooling, the milk substrate was fermented using yoghurt culture CCDM 528 (Streptococcus thermophilus and Lactobacillus delbruckii subsp. Bulgaricus; Laktoflora ${ }^{\circledR}$, MILCOM a.s., Prague, Czech Republic) with added probiotic cultures of Bifidobacterium animalis subsp. lactis (Bb12, Chr. Hansen, Horshølm, Denmark) and Lactobacillus acidophilus (CCDM 151, Laktoflora ${ }^{\circledR}$, MILCOM a.s., Prague, Czech Republic) at $30^{\circ} \mathrm{C}$ for $16-18 \mathrm{~h}$.

Yoghurt bacterial counts were determined according to the Czech national standard: ČSN ISO 7889 (2004), Lactobacillus acidophilus counts according to the Czech national standard: ČSN ISO 20128 (2007), and bifidobacteria counts according to Czech national standard: ČSN ISO 29981 (2010). Fructooligosaccharides (FOS) in drinks were determined according to the methodology described by Bohačenko and Pinkrová (2014).

\section{Fatty acid analysis}

The fat in yoghurt drinks was extracted according to the Czech national standard ČSN EN ISO 1211 (2011). Fatty acids were then re-esterified into the corresponding methyl esters (FAMEs) and analysed by gas chromatography (GC) according to the method and GC parameters described by Borková et al. (2018). Thirty-seven FAMEs were identified using external analytical standards (Supelco Merck KGaA, Darmstadt, German). The content of a particular FA was calculated as a ratio of its peak area/sum of all FA peak areas and given in $\mathrm{g} / 100 \mathrm{~g}$ total FA.

\section{Statistical analysis}

The data were analysed in Statistica (ver. 12, Dell Software, Round Pock, TX, USA). The mean comparison was carried out by an independent $\mathrm{t}$-test. The significance of difference was considered at $P<0.05$. Results were expressed as mean value with a standard error of the mean (SEM). 


\section{Results and discussion}

Knowing the genotype of candidate genes of lipogenic enzymes occurring in the population of livestock can provide important information about the production traits of animals (Ogoreve et al., 2009). One of these genes is $L P L$ that may influence fat content and FA profile in sheep milk (Crisà et al., 2010).

A molecular study showed three combinations of genotypes CTCTAT, CCCCAA and TTTTTT at positions $74(\mathrm{~T} / \mathrm{C}), 130(\mathrm{~T} / \mathrm{C})$ and $133(\mathrm{~T} / \mathrm{A})$ in the 3'UTR region of the sheep $L P L$ gene, respectively. In the tested population the genotypes $\mathrm{CT}(74 \mathrm{~T} / \mathrm{C})$, CT (130T/C) and AT (133T/A) (54.7\%) largely prevail, followed by the genotypes CC (74T/C), CC (130T/C) and AA (133T/A) (33.8\%) (Table 1). Similar frequencies of genetic SNPs have been obtained only in an Italian sheep population (Crisà et al., 2010 ) in the $3^{\prime}$ UTR region of the $L P L$ gene. Other studies of the genetic polymorphism of these SNPs have not been presented, so we cannot compare the current result. However, the latest study by Hidayati et al. (2015) describes the novel SNPs of the $L P L$ gene in Indonesian sheep.

For the pooled milk samples, differences between groups A and B were evaluated for basic milk parameters: the content of fat, protein, lactose and total solids of sheep milk (Table 2). In our study, statistically significant differences in fat content between groups A and B were observed, depending on genotype combinations of the $L P L$ locus (Table 2). In group B with CTCTAT genotype of the $L P L$ locus, higher fat and total solid contents compared to group A with CCCCAA genotype was statistically significant. Differences between the content of protein and lactose of both groups were not significant (Table 2). Although the effect of $L P L$ locus on milk fat content has already been reported by Chilliard et al. (2003), Crisà et al. (2010), Marchitelli et al.

Table 2. Average composition of composite milk for genotype groups, $\mathrm{g} / 100 \mathrm{~g}$

\begin{tabular}{lccl}
\hline \multirow{2}{*}{ Indices } & \multicolumn{2}{l}{ Group $^{1}$} & P-value \\
\cline { 2 - 4 } & $\mathrm{A}$ & $\mathrm{B}$ & \\
\hline Fat & $4.37 \pm 0.05^{\mathrm{b}}$ & $4.66 \pm 0.07^{\mathrm{a}}$ & 0.006 \\
Protein & $4.43 \pm 0.13$ & $4.74 \pm 0.05$ & 0.062 \\
Lactose & $4.83 \pm 0.04$ & $4.88 \pm 0.03$ & 0.304 \\
Total solids & $14.33 \pm 0.17^{\mathrm{b}}$ & $15.05 \pm 0.07^{\mathrm{a}}$ & 0.003 \\
\hline
\end{tabular}

${ }^{1}$ genotype groups according to Table 1 ; the results are reported as mean \pm standard error of the mean; ${ }^{\text {ab }}$ - values with different superscripts in each row are significantly different at $P<0.05$; number of animals in groups for the creation of composite milk samples $=10$ and number of composite milk samples $=6(n=6)$
(2013) and Hidayati et al. (2015); only in the study by Crisà et al. (2010) the relationship between genetic polymorphism in the 3'UTR region of $L P L$ gene and CLA content in milk sheep was evaluated.

However, the aim of the present study was to examine the influence of genetic polymorphism of $L P L$ on FA profile in sheep milk and yoghurt drink. Probiotic yoghurt drinks with prebiotics Bifidobacterium animalis subsp. lactis and Lactobacillus acidophilus were produced only for this purpose. The counts of yoghurt bacteria and probiotic bacteria meet the Czech legislation requirement (Regulation No. 397/2016) for these products (Table 3). In yoghurt bacteria, the need is $\times 10^{7} \mathrm{CFU}$; however, $\times 10^{9} \mathrm{CFU}$ has been found in yoghurt drinks. A dairy product identified as a probiotic should contain at least $\times 10^{6}$ probiotic bacteria. A total of $\times 10^{8}$ Bifidobacterium and Lactobacillus acidophilus was found in drinks in the present study. The fructooligosaccharides (FOS) content measured in drinks after fermentation was at least $4 \mathrm{~g}$ per $100 \mathrm{~g}$ of product (Table 3).

Table 3. The counts of yoghurt and probiotic bacteria and inulin content in yoghurt drinks from sheep milk

\begin{tabular}{lll}
\hline Indices & Group 1 \\
\cline { 2 - 3 } & $\mathrm{A}$ & $\mathrm{B}$ \\
\hline$\Sigma$ yoghurt bacteria, log CFU/g & $9.01 \pm 0.20$ & $9.07 \pm 0.10$ \\
Bifidobacteria, log CFU/g & $7.49 \pm 0.27$ & $7.55 \pm 0.27$ \\
Lactobacillus acidophilus, & $8.42 \pm 0.28$ & $8.38 \pm 0.25$ \\
$\log$ CFU/g & $4.34 \pm 0.21$ & $4.37 \pm 0.25$ \\
FOS, g/100 g
\end{tabular}

${ }^{1}$ genotype groups according to Table 1 ; mean \pm standard deviation $(n=6) ; F O S$ - fruktooligosacharides

The FA profile of two genotype combinations in sheep milk and yoghurt drinks showed statistically significant differences in palmitic acid content and the sum of hypercholesterolaemic FAs (the sum of lauric (C12:0), myristic (C14:0) and palmitic (C16:0) acids) (Table 4). In group A a significantly higher content of palmitic acid than in group B was noted. The trend was also observed as group B showed lower SFA $(P=0.074)$ and higher MUFA $(P=0.067)$ content than group A (Table 4$)$. There were no significant differences in FA content between milk and yoghurt drinks. The present study has not confirmed significant differences between CLA and genetic polymorphism as it was presented in the study of Crisà et al. (2010). This difference might be caused by many factors like as animal origin, selection, breeding programme etc. (Marchitelli et al., 2013). 
Table 4. Fatty acid composition of sheep milk and yoghurt drinks, g/100 g total fatty acid (FA)

\begin{tabular}{|c|c|c|c|c|c|c|}
\hline \multirow{2}{*}{ Indices } & \multicolumn{2}{|l|}{ Milk - group ${ }^{1}$} & \multirow{2}{*}{$P$-value } & \multicolumn{2}{|c|}{ Yoghurt drink - groups ${ }^{1}$} & \multirow{2}{*}{$P$-value } \\
\hline & $\mathrm{A}$ & $\mathrm{B}$ & & $\mathrm{A}$ & $\mathrm{B}$ & \\
\hline$\overline{C 4: 0}$ & $3.19 \pm 0.08$ & $3.22 \pm 0.08$ & 0.827 & $3.19 \pm 0.10$ & $3.19 \pm 0.02$ & 0.960 \\
\hline C6:0 & $2.55 \pm 0.07$ & $2.46 \pm 0.07$ & 0.373 & $2.55 \pm 0.07$ & $2.47 \pm 0.06$ & 0.366 \\
\hline C8:0 & $2.25 \pm 0.08$ & $2.16 \pm 0.08$ & 0.462 & $2.24 \pm 0.08$ & $2.17 \pm 0.07$ & 0.543 \\
\hline C10:0 & $6.35 \pm 0.26$ & $6.03 \pm 0.26$ & 0.414 & $6.34 \pm 0.27$ & $6.06 \pm 0.25$ & 0.463 \\
\hline $\mathrm{C} 12: 0$ & $3.24 \pm 0.11$ & $3.16 \pm 0.08$ & 0.573 & $3.25 \pm 0.11$ & $3.19 \pm 0.08$ & 0.668 \\
\hline $\mathrm{C} 14: 0$ & $9.21 \pm 0.11$ & $9.01 \pm 0.12$ & 0.230 & $9.22 \pm 0.11$ & $9.07 \pm 0.10$ & 0.328 \\
\hline C16:0 & $24.07 \pm 0.30^{\mathrm{a}}$ & $23.19 \pm 0.23^{b}$ & 0.040 & $24.10 \pm 0.29^{a}$ & $23.23 \pm 0.21^{b}$ & 0.037 \\
\hline C16:1 & $0.72 \pm 0.02$ & $0.72 \pm 0.02$ & 0.961 & $0.73 \pm 0.02$ & $0.73 \pm 0.02$ & 0.900 \\
\hline C18:0 & $10.99 \pm 0.36$ & $11.25 \pm 0.56$ & 0.708 & $10.97 \pm 0.36$ & $11.19 \pm 0.54$ & 0.748 \\
\hline$t-C 18: 1^{2}$ & $4.20 \pm 0.35$ & $4.67 \pm 0.15$ & 0.254 & $4.20 \pm 0.35$ & $4.65 \pm 0.16$ & 0.263 \\
\hline c9-C18:1 & $19.05 \pm 0.62$ & $19.6 \pm 0.42$ & 0.479 & $19.03 \pm 0.62$ & $19.55 \pm 0.39$ & 0.492 \\
\hline$c-C 18: 1^{3}$ & $1.70 \pm 0.09$ & $1.80 \pm 0.05$ & 0.340 & $1.71 \pm 0.09$ & $1.79 \pm 0.05$ & 0.433 \\
\hline$t-C 18: 2^{4}$ & $1.61 \pm 0.15$ & $1.72 \pm 0.08$ & 0.518 & $1.62 \pm 0.14$ & $1.72 \pm 0.08$ & 0.531 \\
\hline$c 9, c 12-C 18: 2$ & $2.73 \pm 0.08$ & $2.67 \pm 0.05$ & 0.554 & $2.72 \pm 0.09$ & $2.67 \pm 0.05$ & 0.594 \\
\hline$c 9, c 12, c 15-C 18: 3$ & $2.17 \pm 0.09$ & $2.17 \pm 0.04$ & 0.996 & $2.16 \pm 0.09$ & $2.16 \pm 0.05$ & 0.994 \\
\hline CLA & $1.08 \pm 0.08$ & $1.21 \pm 0.07$ & 0.280 & $1.08 \pm 0.08$ & $1.21 \pm 0.07$ & 0.260 \\
\hline SFA & $65.06 \pm 0.59$ & $63.69 \pm 0.35$ & 0.074 & $65.07 \pm 0.59$ & $63.77 \pm 0.36$ & 0.090 \\
\hline MUFA & $26.72 \pm 0.48$ & $27.88 \pm 0.30$ & 0.067 & $26.71 \pm 0.48$ & $27.82 \pm 0.29$ & 0.078 \\
\hline PUFA & $8.22 \pm 0.35$ & $8.43 \pm 0.18$ & 0.613 & $8.22 \pm 0.34$ & $8.41 \pm 0.18$ & 0.625 \\
\hline $\mathrm{n}-6 \mathrm{FA}$ & $3.04 \pm 0.09$ & $3.00 \pm 0.06$ & 0.689 & $3.04 \pm 0.09$ & $2.99 \pm 0.06$ & 0.632 \\
\hline$n-3 F A$ & $2.49 \pm 0.09$ & $2.50 \pm 0.05$ & 0.905 & $2.48 \pm 0.08$ & $2.49 \pm 0.05$ & 0.904 \\
\hline de novo $\mathrm{FA}^{6}$ & $14.34 \pm 0.43$ & $13.87 \pm 0.44$ & 0.460 & $14.33 \pm 0.43$ & $13.89 \pm 0.39$ & 0.468 \\
\hline hyperchol. FA & $36.53 \pm 0.33^{\mathrm{a}}$ & $35.36 \pm 0.36^{b}$ & 0.037 & $36.57 \pm 0.31^{a}$ & $35.48 \pm 0.32^{b}$ & 0.037 \\
\hline$n-6 / n-3$ & $1.23 \pm 0.04$ & $1.20 \pm 0.04$ & 0.664 & $1.23 \pm 0.04$ & $1.20 \pm 0.04$ & 0.632 \\
\hline
\end{tabular}

${ }^{1}$ genotype groups according to Table $1 ;{ }^{2}$ trans isomers C18:1 (including, e.g., vaccenic acid; t11-C18:1); ${ }^{3}$ cis isomers C18:1 (without c9-C18:1); ${ }^{4}$ trans isomers C18:2 (including, e.g., $\left.t 11, C 15-C 18: 2\right) ;{ }^{6}$ de novo FA: sum C4:0, C6:0, C8:0 and C10:0; ${ }^{7}$ hypercholesterolaemic FA: sum of C12:0, C14:0 and C16:0; CLA - conjugated linoleic acid (mixture of isomers c9t11-C18:2 and c9t11-C18:2); SFA - saturated fatty acid; MUFA - monounsaturated fatty acid; PUFA - polyunsaturated fatty acid; ab - values with different superscripts within each row for milk and yoghurt separately are significantly different at $P<0.05$; results are reported as mean \pm standard error of the mean

However, the best results were obtained for genetic group B milk with CTCTAT genotype combination for $L P L$. This milk had a higher content of fat and total solids but a lower content of palmitic acid and hypercholesterolaemic FA. Hypercholesterolaemic FAs (lauric, myristic and palmitic acids) increase plasma total and low-density lipoprotein (LDL) cholesterol levels. A diet rich in these FAs may increase the risk of cardiovascular disease (Ulbrich and Southgate, 1991). We are convinced that these preliminary results provide an essential finding of the influence of the given $L P L$ haplotype genetic polymorphism on milk and milk products quality. In this study we have analysed the results obtained by repeated measurements of the given genetic group pooled samples of milk to reveal how the situation could change after genetic regulation (selection) on a farm. In further research, the obtained results should be verified on individual samples of sheep milk, and we should procure milk samples with TTTTTT genotype combination, e.g., in cooperation with other farms (from animals of the given breed and genotype group that must be in sim- ilar number of lactations and in a similar lactation stage. We failed to create such a group for our research). It will be required to genotype more animals (especially with genotype TTTTTT) for a better understanding of the genetic effect of candidate lipogenic genes like $L P L$ on FA composition in sheep milk and its products. Knowledge of the genotype of candidate genes of lipogenic enzymes occurring in the population of livestock can provide important information about the production traits of animals (Ogorevc et al., 2009).

\section{Conclusions}

Targeted sheep milk production from animals with different genotypes of the lipogenic enzymes of the lipoprotein lipase gene $(L P L)$ may have a positive influence on the fatty acid profile in milk and products made from it. According to the $L P L$ gene polymorphism, the sheep selection brings the opportunity to make a product with the more beneficial fatty acid profile, but the further research is required. 


\section{Funding}

This research was supported by the Ministry of Agriculture of the Czech Republic, institutional support MZE-RO0718 (V001) and MZE-RO1420.

\section{Conflict of interest}

The authors declare that there is no conflict of interest.

\section{References}

Barber M.C., Clegg R.A., Travers M.T., Vernon R.G., 1997. Lipid metabolism in the lactating mammary gland. Biochim. Biophys. Acta 1347, 101-126, https://doi.org/10.1016/S00052760(97)00079-9

Bauman D.E., Griinari J.M., 2003. Nutritional regulation of milk fat synthesis. Ann. Rev. Nutr. 23, 203-227, https://doi.org/10.1146/ annurev.nutr.23.011702.073408

Bohačenko I., Pinkrová J., 2014. Fructan content determination by HPLC method with refractomeric detection. Listy Cukrov. Repar. 130, 28-32

Bonnet M., Leroux C., Chilliard Y., Martin P., 2000. Rapid communication: Nucleotide sequence of the ovine lipoprotein lipase cDNA. J. Anim. Sci. 78, 2994-2995, https://doi. org/10.2527/2000.78112994x

Borková M., Šulc M., Novotná K., Smolová J., Hyršlová I., Fantová M., Elich O., 2018. The influence of feed supplementation with linseed oil and linseed extrudate on fatty acid profile in goat yoghurt drinks. Mljekarstvo 68, 30-36, https://doi. org/10.15567/mljekarstvo.2018.0104

Bouwman A.C., Bovenhuis H., Visker M.H.P.W., van Arendonk J.A.M., 2011. Genome-wide association of milk fatty acids in Dutch dairy cattle. BMC Genet. 12, 43, https://doi. org/10.1186/1471-2156-12-43

Buccioni A., Serra A., Minieri S., Mannelli F., Cappucci A., Benvenuti D., Rapaccini S., Conte G., Mele M., 2015. Milk production, composition, and milk fatty acid profile from grazing sheep fed diets supplemented with chestnut tannin extract and extruded linseed. Small Rumin. Res. 130, 200 207, https://doi.org/10.1016/j.smallrumres.2015.07.021

Chilliard Y., Ferlay A., Rouel J., Lamberet G., 2003. A review of nutritional and physiological factors affecting goat milk lipid synthesis and lipolysis. J. Dairy Sci. 86, 1751-1770, https:// doi.org/10.3168/jds.S0022-0302(03)73761-8

Crisà A., Marchitelli C., Pariset L., Contarini G., Signorelli F., Napolitano F., Catillo G., Valentini A., Moioli B., 2010. Exploring polymorphisms and effects of candidate genes on milk fat quality in dairy sheep. J. Dairy Sci. 93, 3834-3845, https:// doi.org/10.3168/jds.2009-3014

ČSN EN ISO 1211, 2011. Milk - Determination of fat content Gravimetric method (Reference method). Czech Office for Standards, Metrology and Testing. Prague (Czech Republic)

ČSN ISO 20128, 2007. Milk products - Enumeration of presumptive Lactobacillus acidophilus on a selective medium - Colonycount technique at $37^{\circ} \mathrm{C}$. Czech Office for Standards, Metrology and Testing. Prague (Czech Republic)
ČSN ISO 29981, 2010. Milk products - Enumeration of presumptive bifidobacteria - Colony-count technique at $37^{\circ} \mathrm{C}$. Czech Office for Standards, Metrology and Testing. Prague (Czech Republic)

ČSN ISO 7889, 2004. Yoghurt - Enumeration of characteristic microorganisms - Colony-count technique at $37^{\circ} \mathrm{C}$. Czech Office for Standards, Metrology and Testing. Prague (Czech Republic)

Hidayati H., Sumanti C., Noor R.R., Priyanto R., Rahayu S., 2015. Single nucleotide polymorphisms of lipoprotein lipase gene and its association with marbling quality in local sheeps. J. Indonesian Trop. Anim. Agric. 40, 1-10, https://doi. org/10.14710/jitaa.40.1.1-10

Korbie D.J., Mattick J.S., 2008. Touchdown PCR for increased specificity and sensitivity in PCR amplification. Nat. Protoc. 3, 1452-1456, https://doi.org/10.1038/nprot.2008.133

Markiewicz-Kęszycka M., Czyżak-Runowska G., Lipińska P., Wójtowski J., 2013. Fatty acid profile of milk - a review. Bull. Vet. Inst. Pulawy 57, 135-139, https://doi.org/10.2478/ bvip-2013-0026

Marchitelli C., Contarini G., De Matteis G., Crisà A., Pariset L., Scatà M.C., Catillo G., Napolitano F., Moioli B., 2013. Milk fatty acid variability: effect of some candidate genes involved in lipid synthesis. J. Dairy Res. 80, 165-173, https://doi. org/10.1017/S002202991300006X

Moioli B., Contarini G., Pariset L., Marchitelli C., Crisà A., Catillo G., Napolitano F., 2012. Genetic variation of C18:1 and C18:2 isomers in sheep milk fat. Small Rumin. Res. 103, 187-193, https://doi.org/10.1016/j.smallrumres.2011.08.009

Ogorevc J., Kunej T., Razpet A., Dovc P., 2009. Database of cattle candidate genes and genetic markers for milk production and mastitis. Anim. Genet. 40, 832-851, https://doi. org/10.1111/j.1365-2052.2009.01921.x

Palmquist D.L., 2006. Milk fat: origin of fatty acids and influence of nutritional factors thereon. In: P.F. Fox, P.L.H. McSweeney (Editors). Advanced Dairy Chemistry Volume 2 Lipids. Springer. Boston, MA (USA), pp. 43-92, https://doi. org/10.1007/0-387-28813-9_2

Regulation No. 397/2016 Coll. on requirements for milk and milk products, frozen creams and edible fats and oils (Vyhláška č. 397/2016 Sb. o požadavcích na mléko a mléčné výrobky, mražené krémy a jedlé tuky a oleje)

Reynolds C.K., Cannon V.L., Loerch S.C., 2006. Effects of forage source and supplementation with soybean and marine algal oil on milk fatty acid composition of ewes. Anim. Feed Sci. Technol. 131, 333-357, https://doi.org/10.1016/j. anifeedsci.2006.06.015

Sánchez J.P., San Primitivo F., Barbosa E., Varona L., de la Fuente L.F., 2010. Genetic determination of fatty acid composition in Spanish Churra sheep milk. J. Dairy Sci. 93, 330-339, https://doi.org/10.3168/jds.2009-2268

Shingfield K.J., Bonnet M., Scollan N.D., 2013. Recent developments in altering the fatty acid composition of ruminant-derived foods. Animal 7, 132-162, https://doi.org/10.1017/ S1751731112001681

Ulbricht T.L.V., Southgate D.A.T., 1991. Coronary heart disease: seven dietary factors. Lancet 38, 985-992, https://doi. org/10.1016/0140-6736(91)91846-M

Untergasser A., Cutcutache I., Koressaar T., Ye J., Faircloth B.C., Remm M., Rozen S.G., 2012. Primer3 - new capabilities and interfaces. Nucleic Acids Res. 40, e115, http://doi. org/10.1093/nar/gks596 